\author{
Urban Waste As Resource For Sustainable Environment \\ Angelo Milone ${ }^{1 \mathrm{a}, \text { Daniele Milone }}{ }^{1 \mathrm{~b}}$, Francesco Claudio Campione ${ }^{2 \mathrm{c}}$, and \\ Salvatore Pitruzzella ${ }^{2 \mathrm{~d}}$ \\ ${ }^{1}$ DEIM - $\quad$ Dipartimento Di Energia, Ingegneria Dell'informazione, E Modelli Matematici, \\ University of Palermo, Palermo 90128, Italy \\ ${ }^{2}$ Facoltà di Architettura Università degli Studi Palermo, Viale delle Scienze 14, \\ Palermo 90128, Italy \\ a angelo.milone@unipa.it - ${ }^{\mathrm{b}}$ daniele.milone@unipa.it \\ c ecologia2006@libero.it - c salvatore.pitruzzella@unipa.it
}

Keywords: Waste to energy plant, Smart cities, Energy saving

\begin{abstract}
The emerging model of waste disposal, develops an integrated approach based on waste reduction, selection, recycling, energy recovery and residual use of landfill. Here we discuss the fundamentals of a proper planning of waste disposal system, specially the thermal recovery, the integration and the methodological approach, either from the environmental and economic point of view.

The growing demand for energy, the resulting environmental problems due to satisfy the demand for energy and the complex-economic system, necessitate the study of new technologies such as energy from municipal solid waste (MSW) obtaining as a result of decrease huge mass of solid waste to sanitary landifill and emissions of landifill gas as $\left(\mathrm{CH}^{4}\right.$ and $\left.\mathrm{CO}^{2}\right)$.

Therefore, we propose to validate a technical, economical and environmental analysis of wastetreatment systems with enphasis on generation of energy.

The recovery of heat from a waste-to-energy plant, can make a useful contribution to the city energy needs. Whilst we have been slow to exploit fully this resource in Sicily, economically in urban areas.
\end{abstract}

\title{
Introduction
}

The production of waste in recent years has assumed ever increase proportions. This increase can be attributed to the improvement of living conditions and the progress of industrial development, which led to significant increase in consumption and the product life cycle are often shorter. This large production of waste, represent a great loss of resources and pressure on the environment, which is extended on the all environmental components: air, water and soil.

Sustainable waste management implies reducing dependence on landfills and increasing recycling and reuse. Planning urban waste management in this framework, bring up a number of issues like public health and the people's livelihood, considering how changing lifestyles, introduction of new technologies and advances in science have taken advantage of the environment. Sustainable waste management, must therefore adopt techniques that are cost effective and efficient.

\section{Waste as resource for sustainable development}

One of the critical issues in smart cities, is waste management that can be defined as the " Collection- Transportation- Processing- Treatment- Recycling or Disposal “ of waste materials to reduce their adverse effects on human health or amenities. In sustainable development, economic progress must be in tandem with preserving the environment. Smart cities use technology to optimise the allocation of resources, drive efficiency and support sustainable living.

Wastes need to be seen not as a problem to be disposed, but as a resource for sustainable development. Disposing solid waste is a common problem and efforts are being made to create 
affordable alternatives for sustainable waste management with methods that are cost-effective and technically feasible.

This involve:

- using materials resources efficiently to reduce the amount of waste produced;

- deal with the waste generated in a way that it aligns with economic, social and environmental goals;

A vision of metropolitan area in evolving from primarily " open loop systems " with one-ways flows of resources (in) and wastes (out), to primarily " closed loop systems " where the definition of wastes and resources become blurred. In other words, cities can become more resourceful.

\section{Urban infrastructures in the smart cities [1]}

Everybody wants benefit from efficient urban infrastructure (such as waste water treatment, waste treatment and Combined heat and power production (CHP), but nobody want to see and definitely must be located in on's own backyard.

According to EU directive for Renewable Energy Sources (RES), the proposals for Energy Efficiency (EE) and according to the EU Energy Efficiency Plan 2011, Smart Cities are how have supposed to develop cost-effective smart grid infrastructure for electricity, heating and cooling. Moreover CHP plants are supposed to be located near or in the cities, in order to transfer renewable energy and surplus heat to the buildings. The solution is an urban and architectural design to form a more socially sustainable city design. By 2050 more than 6 billion people, will live in urban areas, most of them in developing and less-developed countries. The number of megacities (with more than 10 million people) is expected to increase from three in 1975 to 29 by 2025 . These cities contribute to climate change and in turn are affected by its consequences.

Energy saving is considered an important goal in order to minimize the problems by the increase in energy consumption and the relevant effects on the environment. The recovery of heat from a waste to energy plant, can make a usefull contribution to the city energy needs. The current best technology for the low pollution disposal of municipal solid waste (MSW) is burning as fuel, with production of electricity, and heat for district heating and cooling. [2 - 3]

The fig. 1 and the next table 1 shows a flow diagram of energy recovery system from waste for district heating plant and the performance of engines gas and gas turbines. [4]

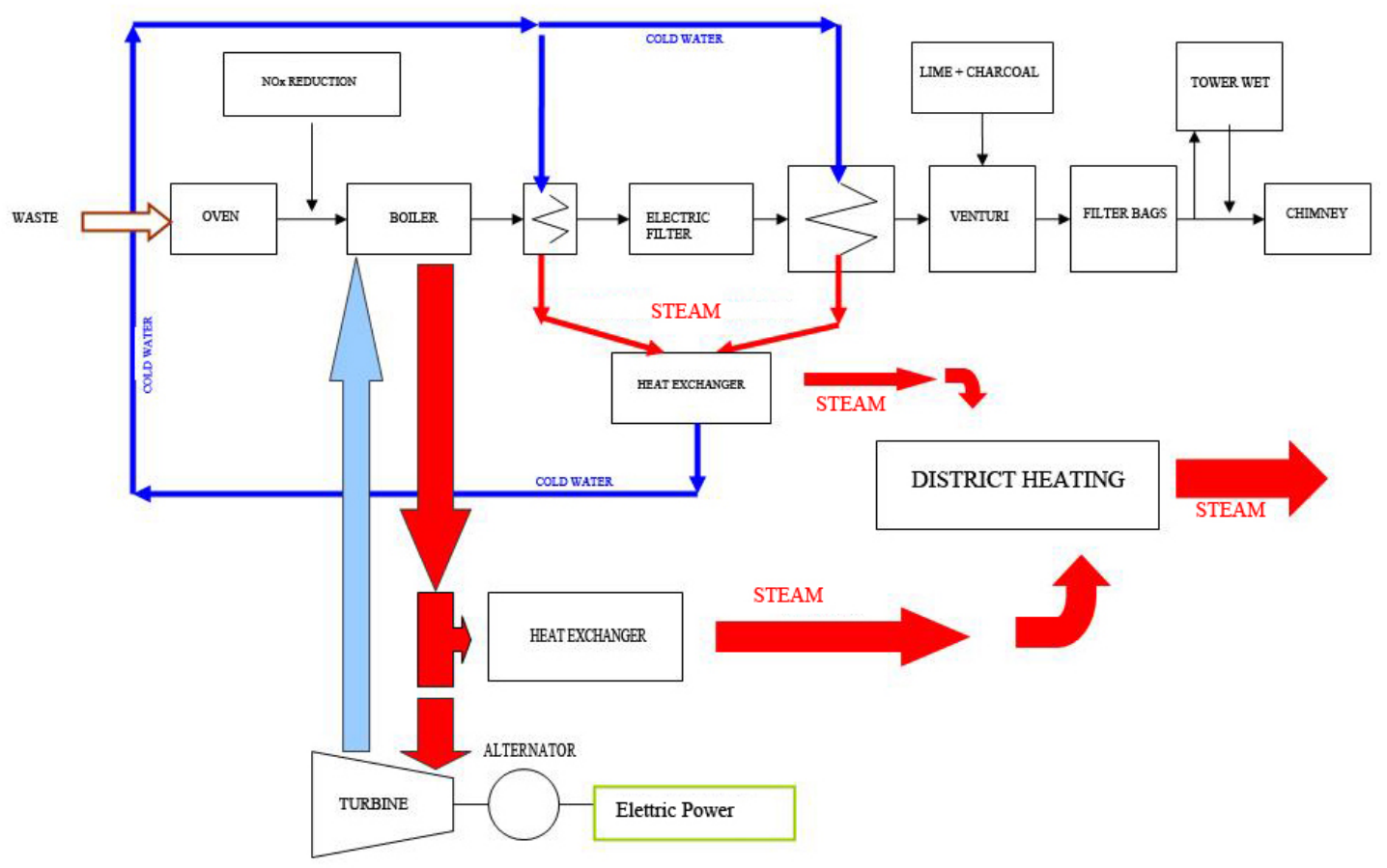

Fig 1 Flow diagram of energy recovery system from waste for district heating plant 
Tab. 1. Performance of engines gas and gas turbines

\begin{tabular}{|c|c|c|c|c|}
\hline \multicolumn{5}{|c|}{ Types cogeneration plants } \\
\hline & Gas turbine & $\begin{array}{c}\text { Alternative } \\
\text { engines }\end{array}$ & Steam turbines & $\begin{array}{c}\text { Combined cycle } \\
\text { gas-steam }\end{array}$ \\
\hline $\begin{array}{l}\text { Power Range } \\
\text { Standard }\end{array}$ & $1 \mathrm{MW}-250 \mathrm{MW}$ & $0,1 \mathrm{MW}-5 \mathrm{MW}$ & 0,5MW-200MW & $\begin{array}{c}5 \mathrm{MW}-350 \\
\text { MW }\end{array}$ \\
\hline $\begin{array}{c}\text { Elettrical } \\
\text { Performance }\end{array}$ & $30 \%-35 \%$ & $30 \%-42 \%$ & $25 \%-35 \%$ & $40 \%-60 \%$ \\
\hline $\begin{array}{l}\text { Total return } \\
\text { system }\end{array}$ & $75 \%-85 \%$ & $75 \%-85 \%$ & $75 \%-85 \%$ & $75 \%-85 \%$ \\
\hline Combustible & $\begin{array}{l}\text { Methane or gas } \\
\text { fuel }\end{array}$ & $\begin{array}{l}\text { Methane or gas } \\
\text { fuel }\end{array}$ & Any fuel, heat recovery & $\begin{array}{l}\text { How to gas } \\
\text { turbine + steam } \\
\text { turbine }\end{array}$ \\
\hline Benefits & $\begin{array}{l}\text { Thermal } \\
\text { recovery at high } \\
\text { temperature }\end{array}$ & $\begin{array}{l}\text { High flexibility, } \\
\text { possibility of } \\
\text { stopping daily }\end{array}$ & $\begin{array}{l}\text { Allows recovery of } \\
\text { waste heat from } \\
\text { industrial processes for } \\
\text { electricity generation }\end{array}$ & $\begin{array}{l}\text { High electrical } \\
\text { efficiency }\end{array}$ \\
\hline
\end{tabular}

\section{Recovery energy from MSW}

The potential of recovery of energy from MSW through different methods, can be made from knowledge of its calorific value and organic fraction, as under. [5]

The most used technologies for energy recovery are distinguished in thermo-chemical in which both the organic component biodegradable non-biodegradable, contribute to the production of energy in output, and in bio-chemistry where only the biodegradable component of the organic substance, can contribute the production of energy.

The Tables 2 and 3 outlines the performance obtained for the two different technological solutions.

Table 2. Thermo-Chemical conversion

\begin{tabular}{|l|l|l|l|}
\hline Total waste quantity: & $\mathrm{Q}$ & $\mathrm{T}$ (Tonnes) & \\
\hline Net Calorific Value: & $\mathrm{NCV}$ & $\mathrm{kWh}$ & \\
\hline Energy recovery potential: $(\mathrm{KW} / \mathrm{h})$ & & $\mathrm{kWh}$ & $\mathrm{NCV}^{*} \mathrm{Q}$ \\
\hline Power generation potential: & & & $\mathrm{NCV}^{*} \mathrm{Q} / 24$ \\
\hline Conversion efficiency: & & $\mathrm{kW}$ & 0,25 \\
\hline Net power generation potential: & & $\mathrm{kW}$ & $0,25^{*} \mathrm{NCV}^{*} \mathrm{Q} / 24$ \\
\hline
\end{tabular}

When $\mathrm{NCV}=4,07 \mathrm{kWh}$ the net power generation is $0,042 * \mathrm{Q}$

In bio-chemical conversion, only the biodegradable fraction of the organic matter can contribute to the energy output: 
Table 3. Bio-Chemical conversion

\begin{tabular}{|l|l|l|l|}
\hline Total Waste Quantity & $\mathrm{Q}$ & $\mathrm{T}$ (tonnes) & \\
\hline Total Organic/Volatile Solids & $\mathrm{VS}$ & & $0,5 * \mathrm{Q}$ \\
\hline Say Organic Bio-degradable Fraction & & & $0,66 * \mathrm{VS}=0,33^{*} \mathrm{Q}$ \\
\hline Typical Digestion Efficiency & & & $60 \%$ \\
\hline Calorific Value of Biogas & $\mathrm{CVB}$ & $\mathrm{kWh} / \mathrm{mc}$ & $5,81 \mathrm{kWh} / \mathrm{mc}$ \\
\hline Energy Recovery Potential & & $\mathrm{kW} / \mathrm{h}$ & $\mathrm{V} * 5,81$ \\
\hline Power generation & & $\mathrm{kW}$ & $\mathrm{V}^{*} 5,81 / 24$ \\
\hline Typical conversion efficiency & & & 0,30 \\
\hline
\end{tabular}

When $\mathrm{CVB}=5,81 \mathrm{~kW} / \mathrm{mc}$ the net power generation is $11,5^{*} \mathrm{Q}$

In order to prove the validity of the system technology described, are summarized in table 4 the estimations of the consumption of fossil fuels for heating a $100 \mathrm{~m}_{2}$ household

Table 4. Fossil fuel and biofuel cost management

\begin{tabular}{|c|c|c|c|c|c|c|}
\hline \multicolumn{7}{|c|}{ Fossil fuels and biofuels } \\
\hline Fuel & U.M & Cost $(€)$ & U.M. & Lower Calorific & Performance & Price (€) \\
\hline Wet Wood & $€ / \mathrm{kg}$ & 0,13 & $\mathrm{kWh} / \mathrm{kg}$ & 4,00 & $85 \%$ & 0,038 \\
\hline Pellets & $€ / \mathrm{kg}$ & 0,29 & $\mathrm{kWh} / \mathrm{kg}$ & 5,00 & $85 \%$ & 0,068 \\
\hline Natural Gas & $€ / \mathrm{mc}$ & 0,76 & $\mathrm{kWh} / \mathrm{mc}$ & 9,50 & $85 \%$ & 0,094 \\
\hline Diesel Fuel & $€ / \mathrm{l}$ & 1,20 & $\mathrm{kWh} / \mathrm{l}$ & 10,00 & $85 \%$ & 0,141 \\
\hline LPG & $€ / \mathrm{l}$ & 0,90 & $\mathrm{kWh} / \mathrm{l}$ & 7,00 & $85 \%$ & 0,151 \\
\hline
\end{tabular}

Table 5. Cost for $100 \mathrm{~m}^{2}$ household

\begin{tabular}{|c|c|c|c|c|}
\hline Fuel & G (days) & H (hours) & Consume $(\mathrm{kW})$ & Cost $(€)$ \\
\hline Wet Wood & 120 & 10 & 8 & 364,8 \\
\hline Pellets & 120 & 10 & 8 & 652,8 \\
\hline Natural Gas & 120 & 10 & 8 & 902,4 \\
\hline Diesel Fuel & 120 & 10 & 8 & 1353,6 \\
\hline LPG & 120 & 10 & 8 & 1449,6 \\
\hline
\end{tabular}

The next table 6 shows the example of a smart city of 100.000 inhabitants and the amount of energy obtainable from MSW respectively as power and thermal energy

Table 6. Perfomance of power and thermal energy recovery for three technical solutions

\begin{tabular}{|l|c|c|c|c|}
\hline Production of MSW for 100,000 Inhabitants $150 \mathrm{~T} /$ day & U.M & $\begin{array}{c}\text { Steam } \\
\text { Turbine }\end{array}$ & $\begin{array}{c}\text { Thermal } \\
\text { engine }\end{array}$ & $\begin{array}{l}\text { Gas } \\
\text { Turbine }\end{array}$ \\
\hline Waste feed- in flow, per hour & $\mathrm{kg} / \mathrm{h}$ & 6250 & 6250 & 6250 \\
\hline Waste low heating value & $\mathrm{kjkg}$ & 14651 & 14651 & 14651 \\
\hline Thermal energy & $\mathrm{kWt}$ & 25436 & 25436 & 25436 \\
\hline $\begin{array}{l}\text { Primary source energy conversion efficiency } \\
\text { steam generator / pyro-gasifier }\end{array}$ & - & 0,78 & 0,60 & 0,70 \\
\hline Thermodynamic cycle global efficiency & - & 0,22 & 0,37 & 0,30 \\
\hline Global net efficiency & - & 0,19 & 0,22 & 0,21 \\
\hline Electric power & $\mathrm{kWe}$ & 4816 & 5596 & 5342 \\
\hline
\end{tabular}




\section{Conclusions}

Smart Cities technologies can provide an important contribution to the sustainable development and energy saving. The District Heating, Cooling and trigeneration system, aims to support communities in their effort to use energy more efficiently.

In Sicily, the consumption of electricity for domestic use (year 2010) was 5.848,3 GWh/year, compared to the total consumption of 18.949,5 GWh,and the consumption of electricity inhabitant/ year is $3.783 \mathrm{KWh} /$ year * inhabitant.

Most of the consumptions are to be attributed to the consumption of power for heat pumps for air conditioning in summer. The total production of solid waste in Sicily in 2009 was 2.408.127 Tonns/year. In this context, the use of the potential of energy from solid waste, can help to reduce Global Warming and Greenhouse Gases Emissions due to increasing demand for fossil fuels for heating, cooling, hot water and electric power in urban areas. [6 - 7]

\section{References and Notes}

[1] Eriksson, O., Finnveden, G., Ekvall, T., Bjorklund, A., 2007. Life cycle assessment for district heating: A compararison of waste incineration, biomass-and natural gas combustion. Energy Policy 35, 1346-1362.

[2] F.C. Campione, A. Milone, D. Milone, 2001. Studio di fattibilità per il teleraffrescamento dai rifiuti solidi, III Convegno Nazionale “ Utilizzazione termica dei rifiuti “, Abano Terme (PD).

[3] F.C. Campione, S. Alterio, A. Campodonico, 2007. Biomasse, fanghi di depurazione e CDR: un sistema energetico integrato. Recycling $\mathrm{n}^{\circ} 4$.

[4] Rosen, M.A., Le, M.N., Dincer, I., 2005. Efficiency analysis of a cogeneration and district energy system. Applied Thermal Engineering 25, 147-159.

[5] Soderman, J., 2007. Optimisation of structure and operation of district cooling networks in urban regions. Applied Thermal Engineering 27, 2665-2676.

[6] S. Alterio, F.C. Campione, A. Milone, D. Milone, 2006, A model sustainable development in areas with limited resources, Proceedings Venice 2006, Biomass and Waste to Energy Symposium Venice, Italy 29 November-1 Decembre 2006;

[7] A. Galatioto, D. Milone, S. Pitruzzella, G. Scaccianoce, Regional policies for sustainability in the Mediterranean countries: the role of a proper HVAC system maintenance in museums, Applied Mechanics and Materials Vols. 316-317 (2013) pp 1147-1151 (C) (2013) Trans Tech Publications, Switzerland doi:10.4028/www.scientific.net/AMM.316-317.1147 